\title{
Characterization of the "in vitro pulp chamber" using the cytotoxicity of phenol
}

C. T. Hanks' ${ }^{1}$, M. L. Diehl' ${ }^{\text {, }}$ R. G. Craig', P.-K. Makinen ${ }^{1}$ and D. H. Pashley ${ }^{2}$

Departments of ${ }^{1}$ Oral Medicine, Pathology and Surgery, of Biological and Materials Sciences, University of Michigan, Ann Arbor, of ${ }^{2}$ Oral Biology-Physiology, Medical College of Georgia Augusta, USA.
Hanks CT, Diehl ML, Craig RG, Makinen P-L, Pashley DH. Characterization of the "in vitro pulp chamber" using the cytotoxicity of phenol. J Oral Pathol Med 1989: 18: 97-107.

Phenol was found to be an acceptable positive control substance for cytotoxicity assays in a new device, the "in vitro pulp chamber" (IVPC). Various concentrations of phenol were used to study its biologic effects on Balb/c 3T3 cells as well as its diffusion characteristics through various thicknesses of dentin disks. The cells showed a linear cytotoxic response to direct contact with phenol between the concentrations of $5 \times 10^{-4}$ and $5 \times 10^{-2} \mathrm{M}$. When a dentin barrier was used in the IVPC, phenol concentrations in the lower chamber were reduced below that in the reservoir and were inversely proportional to the thickness of the dentin. In the IVPC with $0.5 \mathrm{~mm}$ dentin disks, Balb/c $3 \mathrm{~T} 3$ cells growing on the bottom of the dentin disks still maintained new protein synthesis at $60 \%$ of control levels when the phenol concentration in the reservoir was $0.05 \mathrm{M}$. When in direct contact with the cells this phenol concentration depressed protein synthesis to basal levels.
Key words: phenol; pulp chamber.

Carl T. Hanks, The University of Michigan, Department of Oral Medicine, Pathology and Surgery, 5223 School of Dentistry, Ann Arbor, Michigan 48109-1078, U.S.A.

Accepted for publication December 28, 1988.
There are many problems associated with developing an in vitro assay or group of assays which simulate usage tests (1). One is the use of positive control substances to which experimental results between laboratories can be compared. Such substances include polyvinyl chloride (2), phenol (3), or specially fabricated plastics (4). While there is variation in the plasticizers and stabilizers which are used to soften polyvinyl chloride (5), defined positive controls allow consistency and predictability of results. Surprisingly, most in vitro studies of dental restorative products either have not used positive controls or have used zinc oxide-eugenol (ZOE) because of its high toxicity under conditions of direct contact (6-8). The greater cytoxicity of $\mathrm{ZOE}$ in tissue culture compared to usage tests has been used to illustrate the lack of correlation between screening cytotoxicity tests and in vitro usage tests of dental restorative products (9). The biologic actions of eugenol and the reasons for lack of ZOE toxicity in the clinical setting have been summarized by Hume (10). However, since eugenol is slightly soluble in water, it is difficult to develop a concentration-biologic effect curve. Therefore, it would probably not be a good positive reference substance for cytotoxicity tests. Although eugenol is a "dental" material, a reference material need not be a clinical material. Rather, it should give reproducible results in order to test the analytical precision among laboratories (11). To the extent that a toxic substance is soluble, it has the potential to leach out when placed in culture medium or interstitial fluid in tissue. A concentration gradient is created in the tissue, producing a cytotoxic reaction in cells located in that gradient. This condition is also true of materials used in dental cavity preparations, except that dentin creates a non-cellular diffusion gradient which reduces the concentration of soluble substances that reach the cellular pulp. The diffusion gradient across the dentin barrier has been a second problem with developing cytotoxicity tests which bear a relationship to usage tests. The effect of the dentin barrier has not been focused on until recently $(1,10$, 12).

The present study was performed to (a) determine some of the biologic effects of phenol in the cell culture system, (b) determine whether phenol would give reproducible degrees of inhibition in terms of protein synthesis and succinyl dehydrogenase activity and (c) characterize the "in vitro pulp chamber" system in terms of the diffusion of phenol and its effects on cells growing in the "pulp" chamber of the IVPC.

\section{Methods}

Two series of experiments were performed. One determined the nature of the cellular response to phenol and the most appropriate response to use as a positive control for cytotoxicity testing. The second utilized phenol with the cell system in the "in vitro pulp chamber" device, described previously (1), and determined the effect of an interposed dentin disk between the positive control and the cell system.

Balb/c 3 T3 cells (clone A31; American Type Culture Collection, Rockville, Md.) were passaged in T-75 flasks (Corning \#25110) at $1 \times 10^{5}$ cells $/ \mathrm{cm}^{2}$. The cells were maintained in Dulbeccos's modified Eagle's medium (DMEM, Flow Laboratories, McLean, VA) and $10 \%$ newborn calf serum (Gibco, Grand Island, NY) supplemented with penicillin-streptomycin and glutamine. They were passaged ev- 


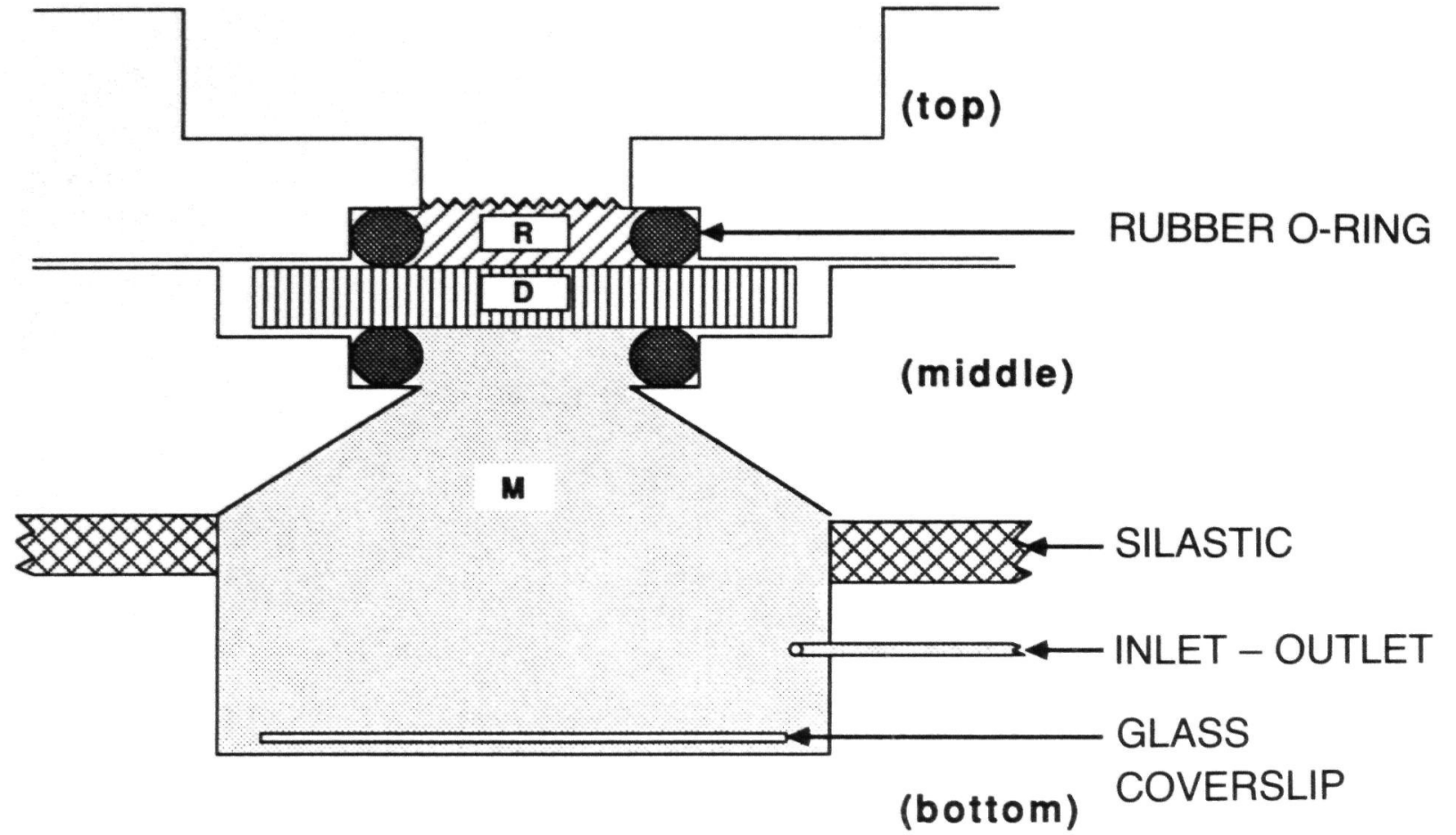

Fig. 1. An individual chamber from "in vitro pulp chamber" device (1). The IVPC is made of three sheets of polycarbonate, the top and middle of which enclose a dentin disk held in place by O-rings. The two plastic sheets are in turn held together by stainless steel thumbscrews. A silastic membrane functions as a gasket between the upper dentin disk assembly and the lower cell chamber sheet with 12 wells containing tissue culture medium. Access to the lower chamber is gained through inlet and outlet ports. Cells are plated either on the "pulpal" surface of the dentin disk or on a glass coverslip at the bottom of the chamber.

ery 3 days before they reached confluence. The cells were plated at $1-$ $2 \times 10^{5} /$ well in 24 -well dishes (Corning \#25820; wells $16 \mathrm{~mm}$ in diameter), on $12 \mathrm{~mm}$ glass coverslips or on EDTAtreated dentin disks for use in the "in vitro" pulp chamber (IVPC) described earlier (1). Of various substrates studied for optimal cells growth as well as optimum visual clarity for densitometric readings of colorimetric cell reactions, borosilicate glass (Rochester Scientific Co., Inc., Rochester, NY) was the most suitable (unpublished data). ${ }^{3} \mathrm{H}$-leucine $(2 \mu \mathrm{Ci} / \mathrm{ml}$; $60 \mathrm{Ci} / \mathrm{mole}$; DuPont NEN, Boston, MA) was incorporated into the culture medium for the 24-h period along with the phenol when measuring the effects of that substance on protein synthesis. The 24 -well dishes were placed in a $5 \% \mathrm{CO}_{2-} 95 \%$ air environment and, thus, were defined as being in an "open system". L-929 cells (NCTC clone 929, American Type Culture Collection, Rockville, Md.) were maintained in F-12 medium (Gibco, Grand Is., NY) with $10 \%$ FCS, but could also be maintained in F-12 alone. Otherwise, they were treated in the same manner as the Balb/c 3T3 cells. $\mathrm{Balb} / \mathrm{c}$ 3T3 cell cultures either in the IVPC (Fig. 1) or in Parafilm- ${ }^{\mathrm{TM}}$ covered 24-well dishes were less exposed to gas exchange and were therefore defined as "closed" systems. A modified culture medium was used to adjust for reduced buffering capacity of the closed systems (1). This modified medium consisted of
McLean, VA), $20 \mathrm{mM}$ Hepes buffer (Calbiochem, LaJolla, CA); $0.5 \mathrm{ml}$ Mito ${ }^{\mathrm{TM}}$ serum extender (Collaborative Research, Bedford, Mass.) and 2.5 $\mathrm{ml}$ donor calf serum (Gibco, Grand Island, NY).

\section{Metabolic tests for effects of phenol in Balb/c 3T3 cells}

The effects of various concentrations of phenol $\left(10^{-5} \mathrm{M}\right.$ to $\left.10^{-1} \mathrm{M}\right)$ were compared in open and closed culture systems. Phenol was a convenient chemical because it has aqueous solubility of about $1 \mathrm{gm} / 15 \mathrm{ml}(0.7 \mathrm{M})$. Confluent cultures of Balb/c 3T3 cells which had been plated on $12 \mathrm{~mm}$ round glass coverslips were treated for $24 \mathrm{~h}$ with a range of phenol concentrations in culture medium containing $2 \mu \mathrm{Ci} / \mathrm{ml}$ of ${ }^{3} \mathrm{H}$ leucine. Effects of phenol in open cultures were observed in standard 24-well dishes. Effects of phenol in closed system cultures were observed in cells in the IVPC either on glass coverslips at the bottom of the chamber or on the undersurface ("pulpal") of the dentin with Earle's salts (Flow Laboratories,

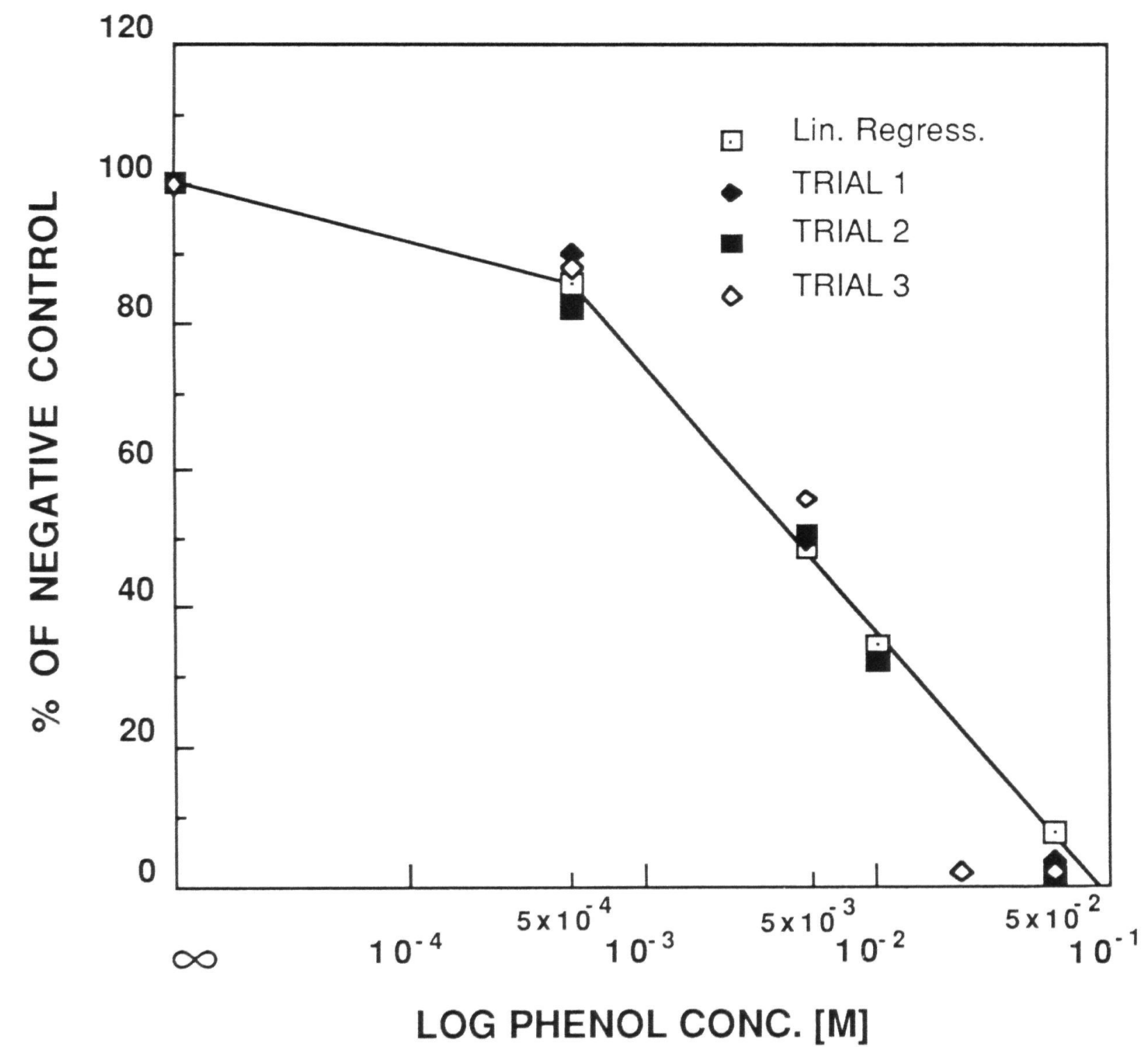

Fig. 2. Composite graph of three trials of the effects of serial concentrations between $0.0 \mathrm{M}$ and $0.05 \mathrm{M}$ phenol on 24-h protein synthesis by Balb/c 3T3 cells maintained on glass coverslips in closed 24 well dishes. The line between the concentrations of $5 \times 10^{-4}$ and $5 \times 10^{-2} \mathrm{M}$ phenol is a linear regression line derived from the readings of the 3 trials. The cell plating concentration was $3 \times 10^{5}$ cells $/ \mathrm{cm}^{2}$. 


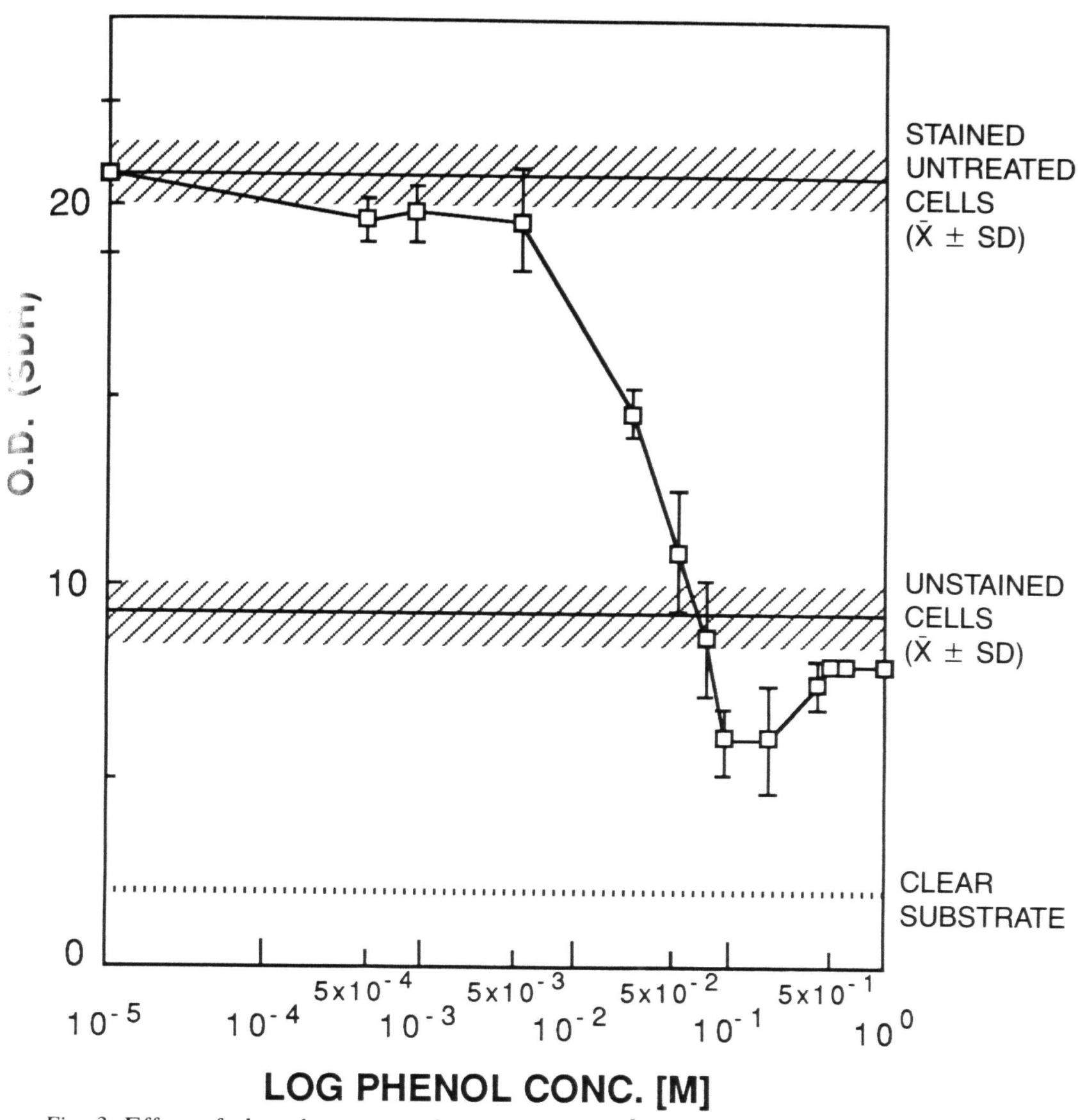

Fig. 3. Effect of phenol concentrations between $10^{-5}$ and $1.0 \mathrm{M}$ on succinyl dehydrogenase activity in Balb/c 3T3 cells plated at $3 \times 10^{5}$ cells $/ \mathrm{cm}^{2}$ and growing on $12 \mathrm{~mm}$ glass coverslips in closed 24-well dishes. Each point represents the mean and standard deviation of 3 densitometric readings. The top horizontal line represents the mean and S.D. of the optical density of SDH-reacted, untreated control cells. The middle horizontal line represents the mean and S.D. of the same concentration of cells on glass substrate, but untreated and unreacted for SDH activity. The bottom horizontal line represents the O.D. of the clear glass substrate.

disks, while phenol was added at various concentrations to the reservoir on the upper surface of the dentin disk (Fig. 1). Fast protein liquid chromatography (FPLC; Pharmacia Inc., Piscata- way, N.J.), with both an anion exchange column and a gel filtration column was used to assess the Balb/c $3 \mathrm{~T} 3$ cells responses to various concentrations of phenol. Phenol-treated cells were gently scraped from $88 \mathrm{~mm}$ diameter tissue culture dishes rather than being trypsinized. They were then centrifuged at $150 \mathrm{X} \mathrm{G}$. washed with warm phosphate-buffered saline (PBS) and recentrifuged into pellets. These cells were resuspended and vortexed in $1 \mathrm{ml}$ of $10 \mathrm{mM}$ Tris- $\mathrm{HCl}$ buffer, $\mathrm{pH} 7.0$, containing $1 \mathrm{mM} \mathrm{CaCl}$. Cell fractionation was accomplished with freeze-thawing cycles, and the cell membranes were spun down at $8800 \mathrm{X} \mathrm{G}$ to clarify the cell lysate for FPLC. Likewise, dentin slabs which had been exposed to various concentrations of phenol were thoroughly perfused with $0.85 \% \mathrm{NaCl}$ and dried, frozen in liquid nitrogen and "powderized" in a $5 \mathrm{ml}$ Teflon chamber with a $5 \mathrm{~mm}$ tungsten carbide grinding ball in a Mikro-Dismembrator II (B. Braun, Burlingame, Calif.). After resuspension of the dentin powder (100 $\mathrm{mg} / \mathrm{ml}$ ) in $10 \mathrm{mM}$ Tris- $\mathrm{HCl}$ buffer, $\mathrm{pH}$ 7.0, containing $1 \mathrm{mM} \mathrm{CaCl}$, the extracts were centrifuged at $12,000 \mathrm{rpm}$ and filtered through $0.2 \mu \mathrm{m}$ Millipore filters (mixed cellulose esters, Millipore Corp., Bedford, Mass.) before placing them on the FPLC columns. After freeze-thawing, cell homogenates were also centrifuged and filtered and then submitted to FPLC. The supernates of the cells as well as the dentin powder were injected into the FPLC columns using a Mono Q HR5/5 anion exchange column. A linear $\mathrm{NaCl}$ gradient ( 0 to 1 M) was applied in the above Tris- $\mathrm{HCl}$ buffer for $72 \mathrm{~min}$ at a rate of $2 \mathrm{ml} / \mathrm{min}$ and the resultant protein profiles were monitored at $214 \mathrm{nM}$. For gel filtration, a Superose 12 column was used. A tris$\mathrm{HCl}$ buffer (containing $50 \mathrm{mM} \mathrm{NaCl}$ ) was used to elute the column at a rate of $0.5 \mathrm{ml} / \mathrm{min}$.

Succinyl dehydrogenase $(\mathrm{SDH})$ en-
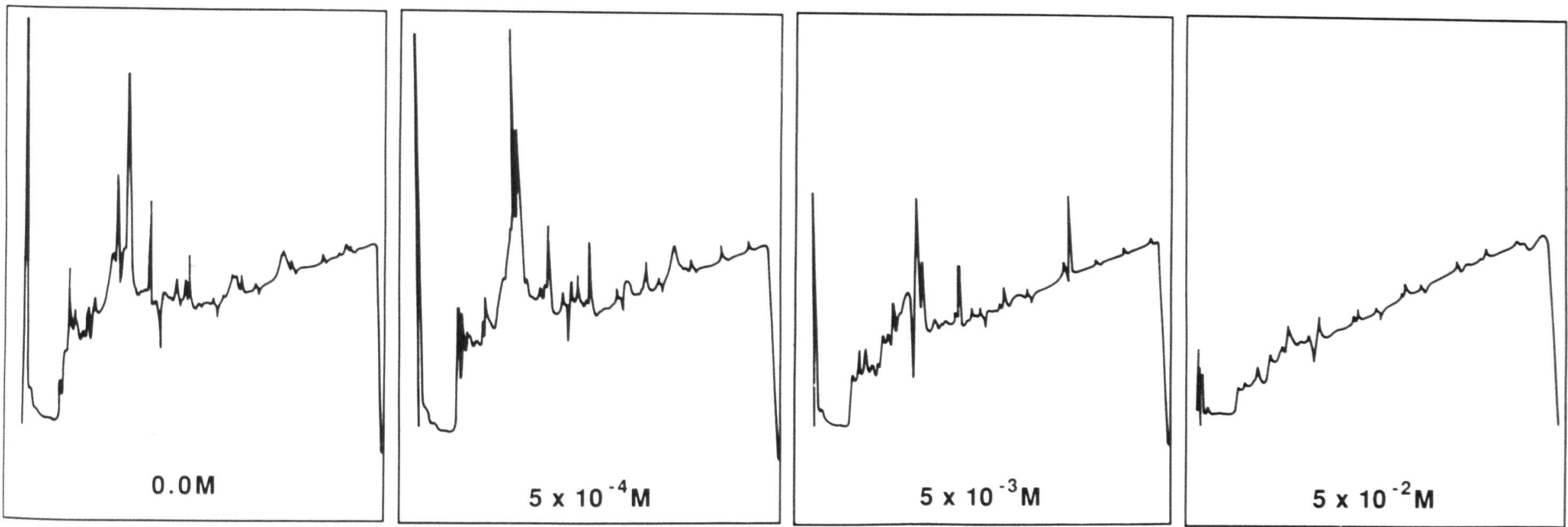

Fig. 4. Protein profiles from $8800 \mathrm{X}$ G supernates taken from Balb/c 3 T3 cells treated for 24 h with phenol in complete medium. The supernates were injected into a Mono Q HR5/5 anion exchange column (FPLC). Proteins from each sample were eluted from the column with a linear $\mathrm{NaCl}$ gradient $(0$ to $1 \mathrm{M})$ in a $10 \mathrm{mM}$ Tris- $\mathrm{HCl}$ buffer, $\mathrm{pH} 7.0$ for 72 minutes. 


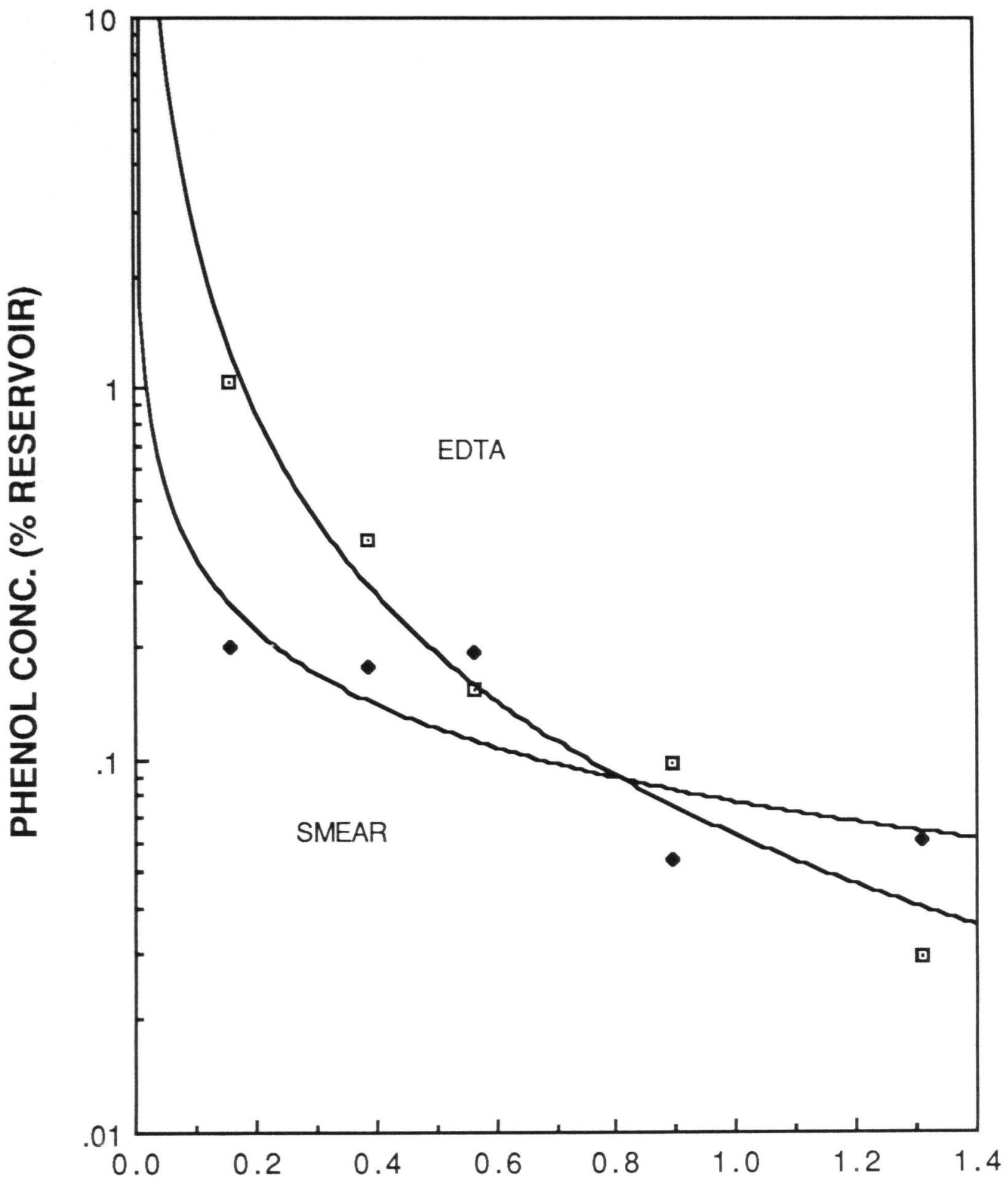

\section{DENTIN THICKNESS $(\mathrm{mm})$}

Fig. 5. A comparison of the concentrations of ${ }^{14} \mathrm{C}$-phenol $(1 \mu \mathrm{Ci} / 0.0091$ umoles phenol in 100 $\mu \mathrm{l}$ of $0.85 \% \mathrm{NaCl}$ solution) in the upper reservoir in the IVPC chamber and the concentrations at the pulpal surface of the dentin disks when the diffusion gradient across the dentin barrier has reached equilibrium. The ordinate was determined by dividing total CPM in the reservoir by total CPM in the diffusate at equilibrium. Seven disks with smear layers were compared to nine disks which had been treated with $0.5 \mathrm{M}$ EDTA for 2 minutes. Disk thicknesses varied from 0.16 to $1.31 \mathrm{~mm}$. The phenol diffused across the dentin disk without the application of hydraulic pressure.

zyme histochemistry of the cell sheet was employed to relate changes in the levels of cellular respiration with changes in morphology and the rates of protein synthesis induced by phenol. $\mathrm{Balb} / \mathrm{c}$ 3T3 cells were plated at $1 \times 10^{5}$ cells $/ \mathrm{cm}^{2}$ on glass coverslips for $24 \mathrm{~h}$, treated with various concentrations of phenol for $24 \mathrm{~h}$, and followed by observation of the monolayers by phase contrast microscopy and analysis of SDH activity. The SDH histochemistry method requires treatment of the monolayer for $3 \mathrm{~h}$ at $37^{\circ} \mathrm{C}$ with an incubating solution of $0.1 \mathrm{ml}$ substrate solution containing disodium succinate and $0.9 \mathrm{ml}$ of stock solution containing a tetrazolium compound which is re-
$0.85 \%$ saline. This dye tends to function like a vital dye, concentrating in living cells which are able to maintain functional plasma membranes. The Hoechst 33258 dye $(30 \mu \mathrm{M})$ was placed in tissue culture medium, complete with serum and the cells were incubated in this medium for $1.5 \mathrm{~h}$ at $37^{\circ} \mathrm{C}$. This dye stains nuclei of living cells distinctly, but dimly, while it stains nuclei of dead and dying cells much more brightly. A Leitz Diavert inverted microscope with appropriate blocks for fluorescent excitation and emission were used to visualize cells.

\section{Effects of phenol on cells in IVPC}

Phenol diffusion was through various thicknesses of dentin which had a smear layer on the coronal surfaces or had been treated with $0.5 \mathrm{M}$ EDTA for $2 \mathrm{~min}$. The dentin disks had been taken from extracted, non-carious permanent molar teeth of young adults. Transverse slabs of dentin covered by enamel were cut from molar crowns with a diamond saw (1). Reduction of the thickness of the dentin disks was done from the coronal rather than pulpal aspect. The crown diameter of the tooth had to be large enough for dentin to fit within the O-rings (I.D. $=4.47 \mathrm{~mm}$ ) of the IVPC and the pulpal slice had to be slightly above the pulpal horn. Thus, dentin tubules were as large, numerous and as patent as possible for each slice. The tubules were oriented in the dentin disk in the IVPC just as they were in the tooth with the larger diameter on the pulpal surface and the tubules converging toward the pulpal horns. A smear layer was obtained during finishing the dentin disk with \#400 and then with \#600 grit sandpaper. After either placing the smear layer or removing it with a 2 -min treatment of $0.5 \mathrm{M}$ tetrasodium enthylenediamine tetra-acetate (EDTA; Fisher Scientific Co., Fair Lawn, N.J.) adjusted to $\mathrm{pH} 7.4$ with 5 $M$ citric acid, the thickness of the dentin disk was measured with a Tumico micrometer (Central Scientific Co., Chicago, IL) to the nearest $0.01 \mathrm{~mm}$. Scanning electron microscopy was used to check the formation of a smear layer and its removal with EDTA. Following the establishment of these routine treatments, the disks with smear layers and EDTA-treated disks were selected for experiments according to their thickness and hydraulic conductance.

The filtration rate and hydraulic conductance (14) for each disk were deter- 


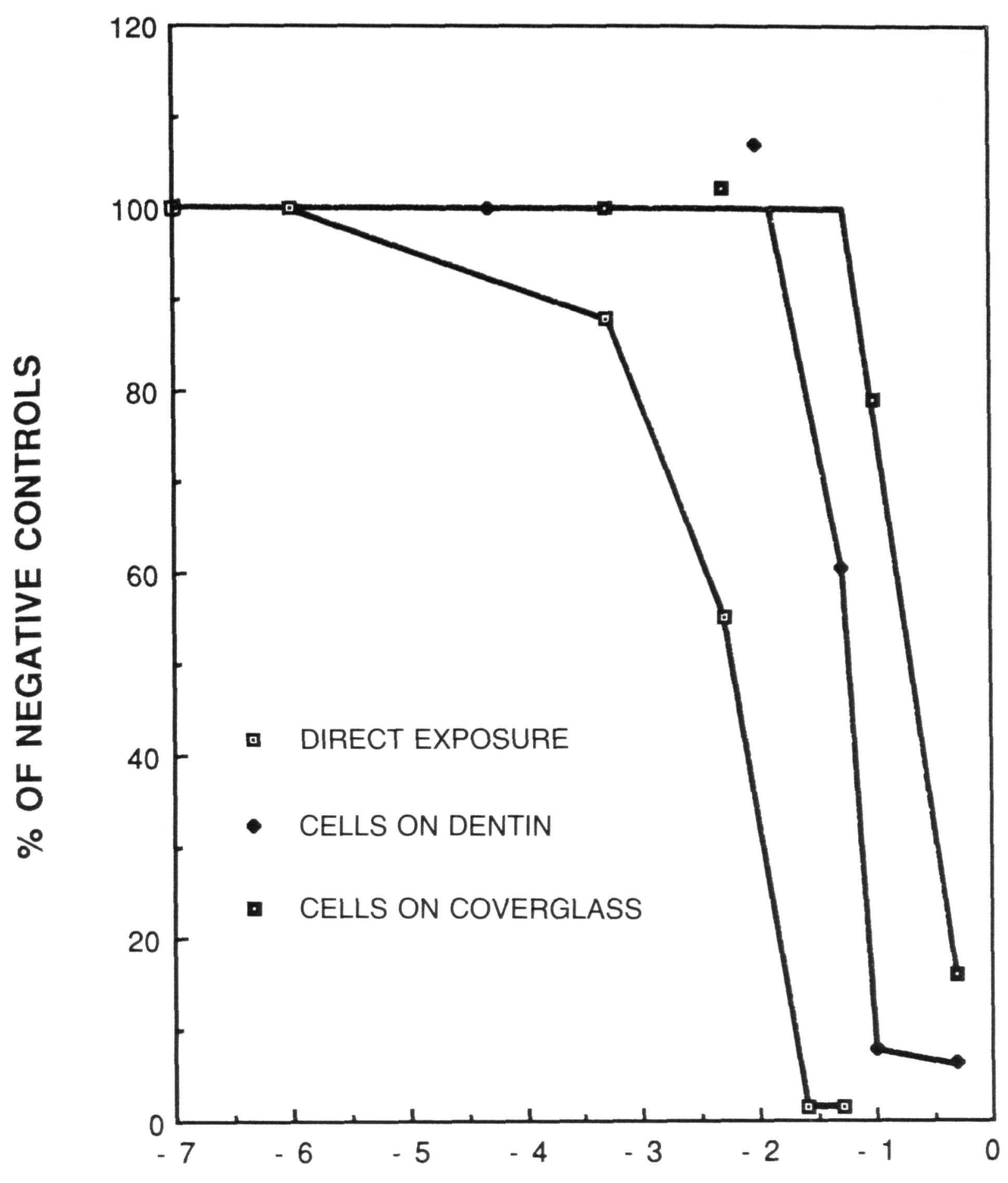

LOG PHENOL CONC. [M]

Fig. 6. A comparison of the effects of various concentrations of phenol in direct contact with Balb/c 3 T3 cells ( $\square-\square$ ), and in the IVPC in which Balb/c 3T3 cells were growing either on the "pulpal" surfaces of dentin disks with an average thickness of $0.55 \mathrm{~mm}$ ( glass coverslips at the bottom of the chamber (- The indicated concentrations of phenol for the IVPC were placed in the reservoir on the "coronal" surfaces of the dentin disks. The 24-h protein synthesis data (uptake of ${ }^{3} \mathrm{H}$-leucine) are expressed as percent of negative control values.

mined at room temperature $\left(21^{\circ} \mathrm{C}\right)$ using a manometer column $180 \mathrm{~cm}$ high, filled with 18 megaohm, degassed water. The manometer was calibrated at various heights $(\mu \mathrm{l} / \mathrm{cm}$ length $)$ and filtration rates were determined at various heights per unit area of dentin. For hydraulic conductance (Lp), the filtration rate was divided by the height of the water column. Filtration rates and hydraulic conductance values were determined with the dentin disks in a "split-chamber" device (15). Diffusion of ${ }^{14} \mathrm{C}$-phenol was also measured in the split chamber device, by placing $100 \mathrm{ul}$ $0.85 \% \mathrm{NaCl}$ solution containing 1 $\mu \mathrm{Ci}^{14} \mathrm{C}$-phenol (0.0091 umoles; Amersham, Arlington Hts., IL) in the upper reservoir representing the "cavity preparation," and measuring the amount of phenol freely diffusing through the dentinal tubules to the "pulp chamber" as a function of time (16). Physiologic saline was used to carry the radioactive phenol away from the pulpal surface of the dentin disk. The $\mathrm{NaCl}$ solution was administered by way of a peristaltic pulp at a drip rate $1.5 \mathrm{ml}$ per min. The $\mathrm{NaCl}$ then dropped freely by gravity into tubes in a fraction collector. No hydraulic pressure was placed on the split chamber-dentin disk system. The diffusion of the same concentration of phenol was measured in all cases for each thickness $(0.16 \mathrm{~mm}-1.31 \mathrm{~mm})$ and treatment (smear vs. 0.5 M EDTA) of dentin.

Finally, Balb/c $3 \mathrm{~T} 3$ cells as well as L-929 cells were grown on the pulpal surface of a series of EDTA-treated dentin disks. For the Balb/c $3 T 3$ cells the thicknesses of the dentin disks ranged from $0.47 \mathrm{~mm}$ and $0.59 \mathrm{~mm}$ (mean and S.D. $=0.55$ and $0.04 \mathrm{~mm}$ ), and the $L p$ values $\left(\mu l \mathrm{~cm}^{-2} \mathrm{~min}^{-1} \mathrm{~cm}\right.$ $\mathrm{H}_{2} \mathrm{O}^{-1}$ ranged between 0.003 and 0.1 (mean and S.D. $=0.024$ and 0.033 ). For L-929 cells the thicknesses of the dentin disks ranged from 0.46 and 0.64 $\mathrm{mm}$ (mean and S.D. $=0.53$ and 0.06 $\mathrm{mm}$ ) and the Lp values ranged between 0.02 and 0.046 (mean and S.D. $=0.032$ and 0.008 ). These cells were plated on the disks at about 280,000 cells $/ \mathrm{cm}^{2}$ (or about 44,000 cells $/ 0.1569 \mathrm{~cm}^{2}$ area of exposed dentin disk within the O-ring) in $100 \mathrm{ul}$ of complete medium. The dentin disk assembly was allowed to sit with cells on the pulpal surface of the dentin disks in the tissue culture $\mathrm{CO}_{2}$ incubator overnight in order to allow attachment of cells. Then, the upper disk assembly was carefully inverted over the polycarbonate block with the lower chambers containing the special IVPC medium with $2 \mu \mathrm{Ci} / \mathrm{ml}^{3} \mathrm{H}$-leucine (Fig. 1). With cells on the pulpal surface of dentin disks in the IVPC assembly, various concentrations of phenol (from $0.0 \mathrm{M}$ to $0.5 \mathrm{M}$ ) in tissue culture medium without serum were placed in the upper reservoirs. For a single IVPC asssembly ( 12 wells), 2 reservoirs were used for each of 5 phenol concentrations and 2 reservoirs contained only medium (controls). After $24 \mathrm{~h}$, the IVPC device was carefully separated, cells on the underside of the disks were treated with fluorescein diacetate to determine the approximate number of cells on the disk. Then, the disks were placed in $0.5 \mathrm{ml} 0.25 \%$ Triton $\mathrm{X}-100$ with $100 \mu \mathrm{l} / \mathrm{ml} 1 \mathrm{~N} \mathrm{NaOH}$ for $15 \mathrm{~min}$ for dissolution of cells. Protein assay showed that this procedure did not dissolve protein from the dentin disk. Aliquots of $50 \mu \mathrm{l}$ were placed on $2.5 \mathrm{~cm}$ circles of Whatman $3 \mathrm{M}$ filter paper for liquid scintillation analysis of leucine incorporation into macromolecular protein. Another lysate aliquot $(100 \mu \mathrm{l})$ from each disk was analyzed for protein content (BCA Protein Assay Reagent, Pierce Chemical Co., Rockford, IL) at $562 \mathrm{~nm}$ in a Beckman 25 spectrophotometer. The new protein synthetic activity was reported as percent of negative controls. Following this first experiment, the dentin disks which had been utilized with the Balb/c 3T3 cells were washed with 18 megaohm sterile water overnight, resterilized overnight with ultraviolet light and re-utilized. The same procedures were 


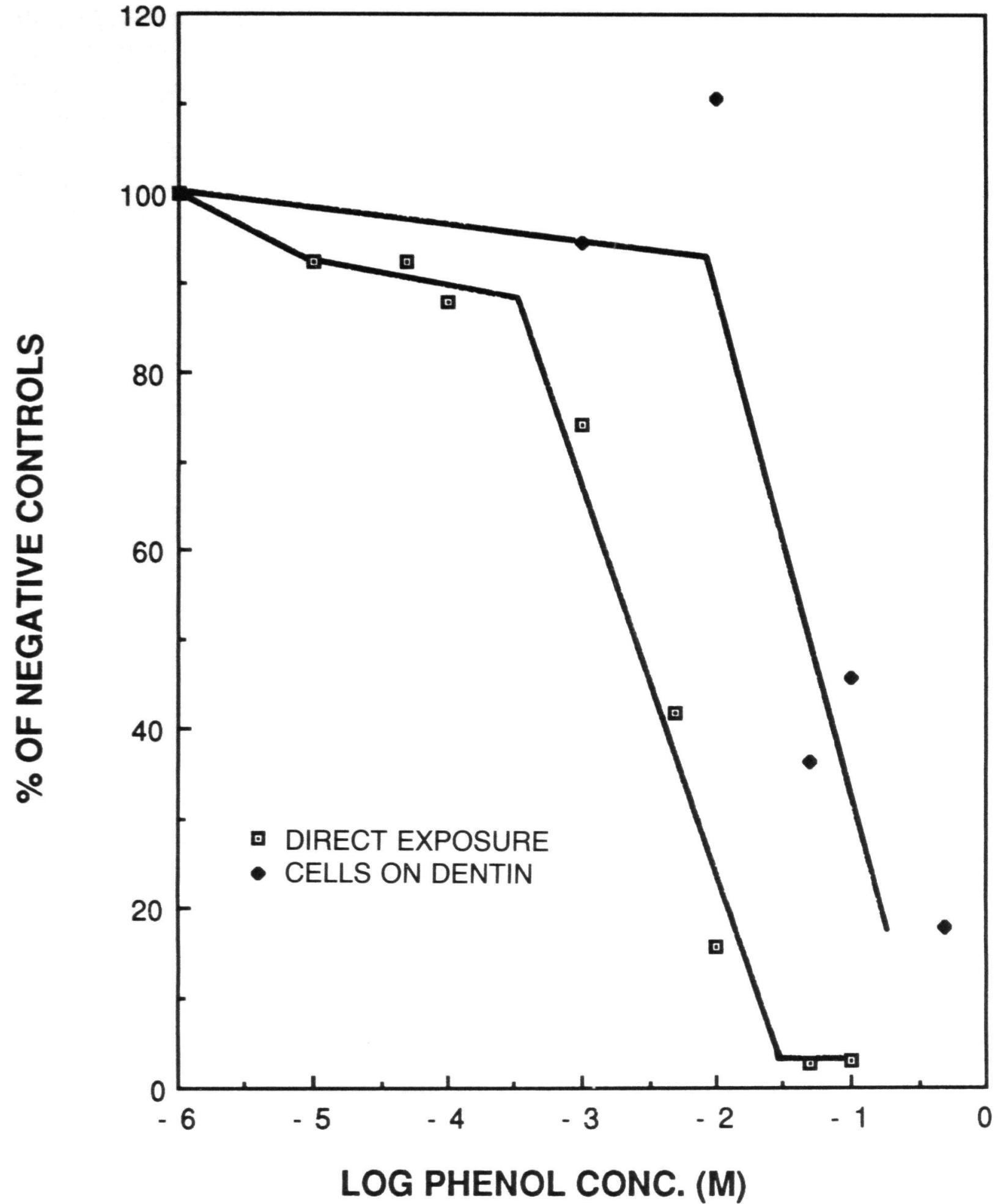

Fig. 7. A comparison of the effects of various concentrations of phenol in direct contact with L-929 cells ( $\square \square \square$ ), and in the IVPC in which L-929 cells were growing on the "pulpal", surfaces of dentin disks with an average thickness of $0.53 \mathrm{~mm}$ ( The indicated concentrations of phenol used in the IVPC were placed in the reservoir on the "coronal" surfaces of the dentin disks. The 24 -h protein synthesis data (uptake of ${ }^{3} \mathrm{H}$-leucine) are expressed as percent of negative control values

followed in this second experiment, except that cells were cultured on glass coverslips at the bottom of the IVPC chambers. The effects of various concentrations of phenol diffusing from the coronal reservoir across the dentin disk on new protein synthesis in Balb/c 3T3 cells growing on the bottom of dentin disks as well as on glass coverslips in the IVPC chambers were compared to the effect of the same concentrations of phenol directly contacting the cells. Cells could be visualized on the pulpal surfaces of dentin disks by epifluorescence microscopy or by scanning electron microscopy, after fixation in $2.5 \%$ glutaraldehyde in $0.1 \mathrm{M}$ cacodylate buffer, post-fixation in $1 \%$ osmium tetroxide, and critical point drying. between $10^{-5}$ and $5 \times 10^{-3} \mathrm{M}$. There was a gradual drop in activity between $5 \times 10^{-3}$ and $10^{-1} \mathrm{M}$ phenol.

Anion exchange chromatography (FPLC) patterns of proteins from the supernates of untreated control cells $(0.0 \mathrm{M}$ phenol) are shown in Fig. 4 . The effect of increasing concentrations of phenol was to reduce the complexity of the proteins, especially the heights and densities of the more negativelycharged protein peaks. By $5 \times 10^{-2} \mathrm{M}$ phenol concentration, there were few soluble proteins left in the cell monolayer. Gel filtration of proteins separated by molecular size showed similar patterns. A similar FPLC anion exchange column was run on extracts of powderized dentin disks after treatment with various concentrations of phenol and the patterns showed no appreciable alteration in the size and number of the few peaks of anionic proteins in powderized dentin.

\section{Diffusion of phenol through dentin in IVPC}

${ }^{14} \mathrm{C}$-phenol diffusion was measured in established concentration gradient conditions in dentin disks under no hydraulic pressure in split-chamber devices. Depending on the thickness of the disk, this gradient was usually established in 15 to $30 \mathrm{~min}$. Fig. 5 compares the relative concentrations of phenol, as percentage of the concentration of ${ }^{14} \mathrm{C}$ phenol placed in the reservoir, under identical conditions $\left(21^{\circ} \mathrm{C}\right.$ room temperature; $0 \mathrm{~cm}$ water height; 0.009 $\mu$ mole phenol in reservoir), to the thickness of the dentin disk. Each point represents a different dentin disk. Although these points are plotted semilogarithmically and the curves are logarithmically fit, it appears that the points overlapped for the most part, whether the disks had a smear layer or not. The thinnest disk measured in this study was $160 \mu \mathrm{m}$, which diluted phenol by approximately 500 times $(0.2 \%$ of reservoir concentration) when a smear layer was present. The same thickness of disk treated with EDTA diluted phenol only 96 times $(1.041 \%$ of reservoir concentration).

The study of phenol effects on Balb/c $3 \mathrm{~T} 3$ cells in the IVPC utilized 12 dentin disks (mean thickness and S.D. $=0.55$ and $0.04 \mathrm{~mm})$. Phenol concentrations of $0.01 \mathrm{M}$ and less, when placed in the reservoir, caused no inhibiton of protein synthesis in cells growing on the dentin disks (Fig. 6). When $0.05 \mathrm{M}$ phenol was placed in the reservoirs, the 

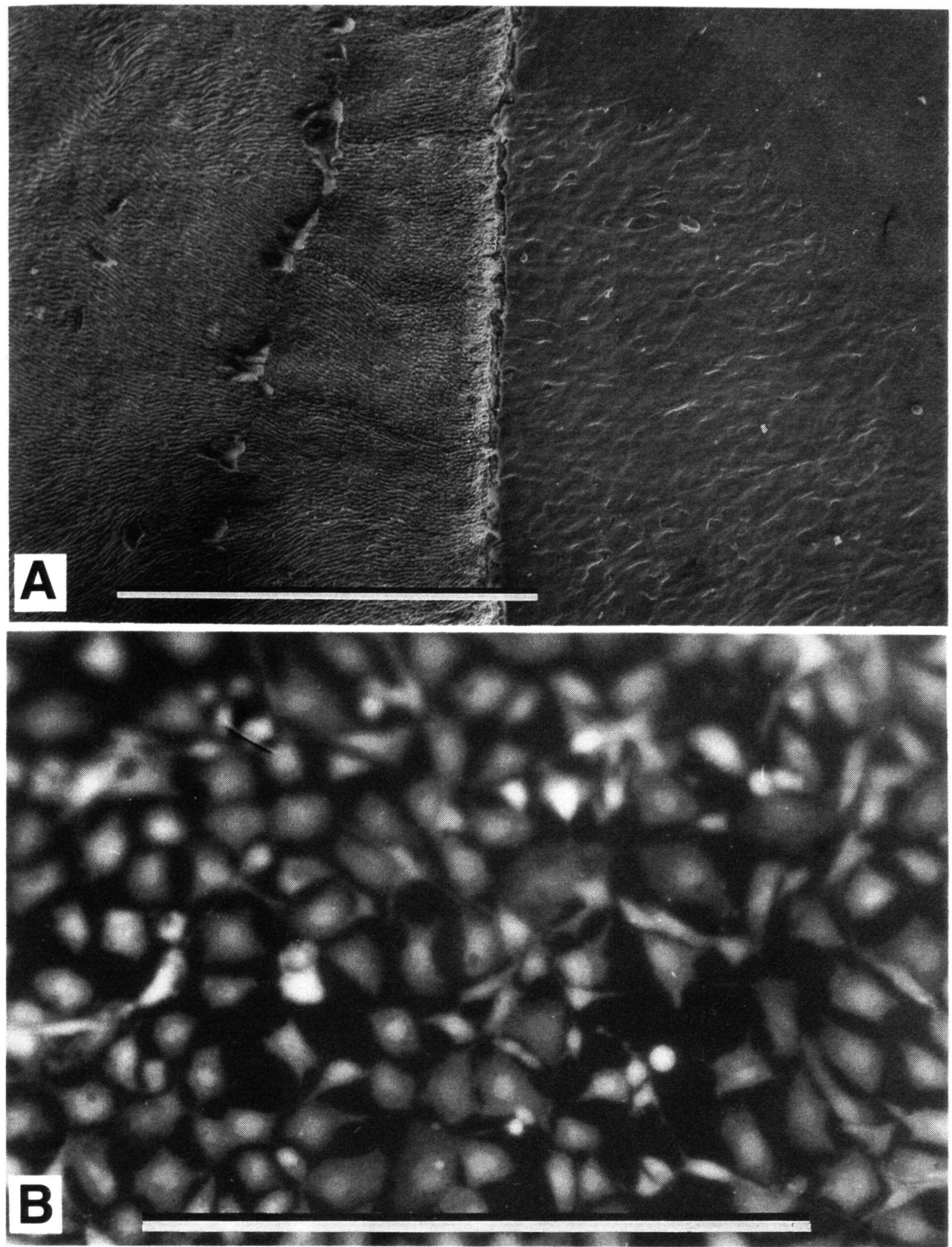

Fig. 8. Balb/c 3T3 cells growing on the "pulpal" surfaces of EDTA-treated dentin disks after being plated at 200,000 cells $/ \mathrm{cm}^{2}$ and maintained for $48 \mathrm{~h}$. These micrographs show (A) cells on cross section of molar tooth with electron microscopy, and (B) cells on cross section of molar tooth after incubation with FDA. The Balb/c 3T3 cells are growing almost exclusively on the dentin. The open dentin tubular orifices of the EDTA-treated dentin disks can be observed in the upper right hand corner of Fig. 13a. Enamel rods can be seen on the left half of this micrograph. (Fig. $13 \mathrm{~A}=\mathrm{X} 100 \mathrm{mag}$., bar $=0.5 \mathrm{~mm}$; Fig. $13 \mathrm{~B}=\mathrm{X} 115 \mathrm{mag}$., bar $=0.5$ $\mathrm{mm})$.

toxic substance was diluted by diffusion through the dentin so that Balb/c 3T3 cells still synthesized protein at about $60 \%$ of the negative control. When the phenol concentration was increased to $0.1 \mathrm{M}$, the diffusion gradient caused dilution of phenol so that the cells still synthesized about $8 \%$ as much new protein as the controls. A second line, representing Balb/c 3T3 cells on glass coverslips in the bottom of the IVPC chambers, showed that the phenol effect was further diluted by the culture medium in the chamber. A phenol concentration of approximately $0.05 \mathrm{M}$ in diffusing through dentin as well as when monolayers of cells were exposed directly to varied concentrations of phenol (Fig. 7).

Balb/c 3T3 cells which were plated on EDTA-treated dentin disks $(200,000$ cells $/ \mathrm{cm}^{2}$ ) for $24 \mathrm{~h}$ could be visualized after staining with a fluorescent dye such as FDA (Fig. 8B) or by S.E.M. (Fig. 8A). The cells appeared to have attached to the cut dentin surface, but not to the enamel surface. Phase contrast microscopy and fluorescent microscopy illustrated that fluorescein was concentrated in the cytoplasm of living, but not dead cells (Fig. 9), while Hoechst 33258 was concentrated in the nuclei of both living and dead cells. However, the fluorescent intensity of Hoechst 33258 in nuclei of the dead cells was greater than in the living cells (Fig. 10).

\section{Discussion}

Several metabolic effects of dilute solutions of phenol upon established cell lines, especially Balb/c 3T3 cells were described. Phenol is a compound which has been used for many years because of observed bacteriocidal, fungicidal, anesthetic and protein denaturation properties (17). Protein denaturation (fixation) was the property most evident in this study. Other effects of phenol are the ability to extract lipopolysaccharides from bacteria (18) and RNA and proteins from eukaryotic cells when used as a hot, undiluted solvent (19). Phenol, like other monophenols such as tyrosine, show little propensity for oxidation, and thus generation of toxic oxygen species in culture medium or interstitial fluid (20).

Concentrations of phenol between $5 \times 10^{-5}$ and $5 \times 10^{-1} \mathrm{M}$ were used in the present studies. Phenol is soluble in water at a concentration of about $0.7 \mathrm{M}$ and this was one of the reasons that phenol was chosen over eugenol as a positive control. While the eugenol molecule is a little larger than that of phenol (m.w. eugenol $=164.2$; m.w. phenol $=94.11)$, the limit of solubility of eugenol in water is about $1.21 \mathrm{mM}$, less than 1/500th of that of phenol $(21,22)$. Various methods have been used to "solubilize" eugenol, e.g. sonication which makes a microsuspension of eugenol (23) or the utilization of a solvent such as methanol (24). However, neither solubilization method allows for an accurate concentration-effect analysis of eugenol. In this study, the 

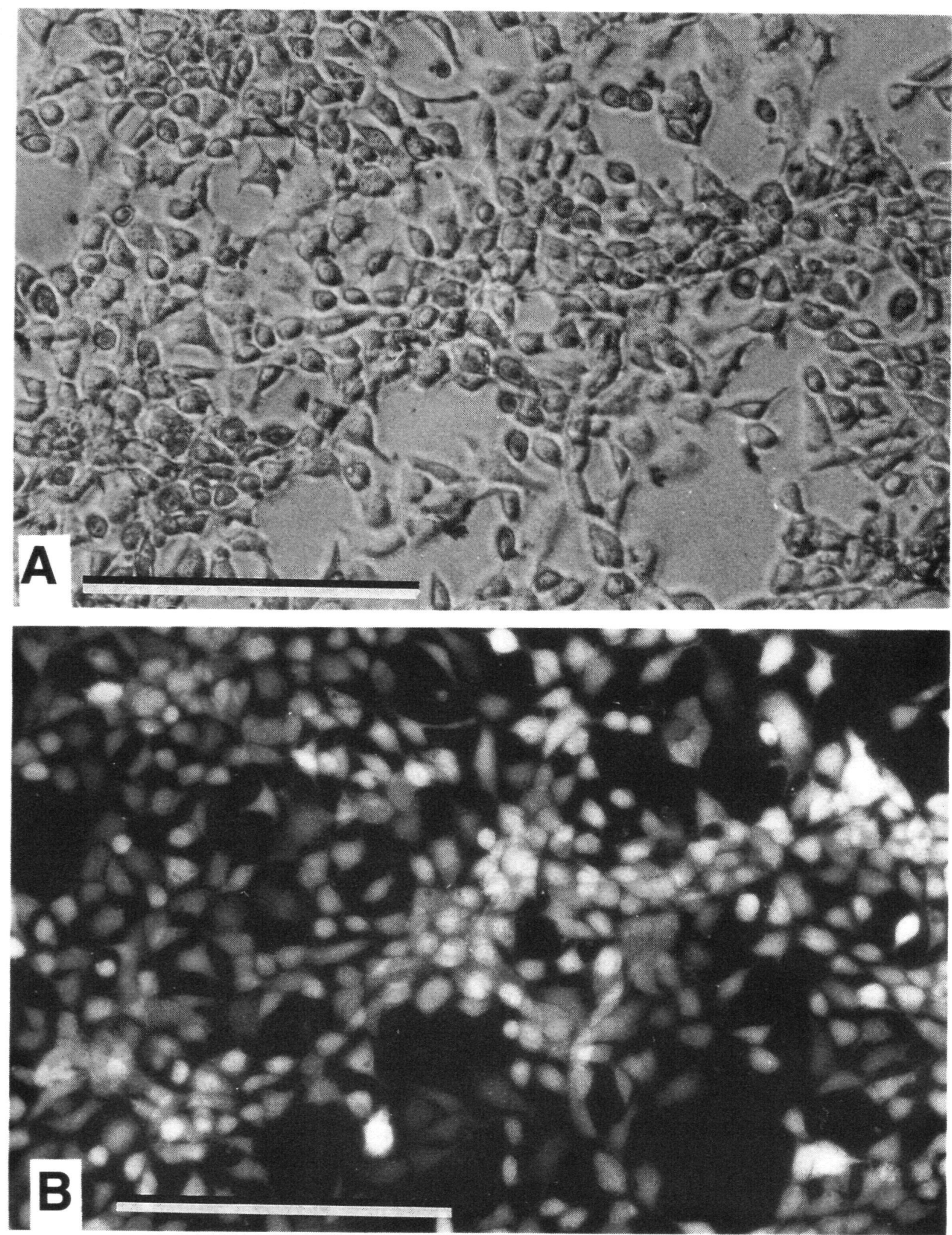

Fig. 9. Balb/c 3 T3 cells directly exposed to $5 \times 10^{-3} \mathrm{M}$ phenol. Phase contrast microscopy (A) shows slight contraction of cellular processes, but very few large gaps; fluorescence microscopy (B) of the same field indicates that most of these cells are living because they are able to sequester fluorescein. Mag. $=$ X117; bars $=250 \mu \mathrm{m}$.

stock solution was $0.5 \mathrm{M}$ phenol in tissue culture medium without serum, from which subsequent dilutions were made. It has been shown that phenol depresses (a) new protein synthesis, (b) cellular aerobic respiration (succinyl dehydrogenase activity), and (c) other cellular metabolic activities such as cell attachment at concentrations between $5 \times 10^{-4}$ and $5 \times 10^{-1} \mathrm{M}$. In an analogy to pulp, cells will be affected, whether they are odontoblasts or cells deeper in the pulp, according to the concentration of phenol.

There was a great deal of agreement between the analytic methods used (Fig. 2, Table 1). This observation suggests for Balb/c 3T3 cells subjected di- rectly to phenol in the tissue culture medium that metabolic functions are gradually turned off by phenol with increasing concentrations between $5 \times 10^{-4}$ and $5 \times 10^{-1}$ M. At about $5 \times 10^{-2} \mathrm{M}$ phenol, the protein denaturation effects were maximal with almost complete inhibition of new protein synthesis, and dramatic reduction of number of cells attached to the substrate and loss of SHD activity. Although this phenol concentration gave low values for all methods of analysis, phase contrast microscopy and the BCA protein assay methods were most gentle to cells on their substrates, and fewer of the loosely attached cells were removed with these analytic methods.
Thus, most of the cells at the phenol concentration of $5 \times 10^{-2} \mathrm{M}$ were loosely attached to both substrate and to each other, and were metabolically quite inactive after $24-\mathrm{h}$ exposure. With a higher concentration of phenol $(0.1$ $\mathrm{M})$, the proteins were denatured faster than all cells could detach, leaving larger numbers of floating cells attached to each other (i.e. sheets of cells) as well as to the substrate, but again without metabolic functions. At $0.5 \mathrm{M}$ phenol, the cells were fixed most quickly, with the retention of all cells as a sheet on the substrate. This fixation of cells did not reduce solubility of the cellular proteins. Because the total cellular protein values (by BCA assay) followed the patterns of FPLC and SDH activity so precisely, it was concluded that reduction of chromatographic protein peaks and O.D. of the cell sheet after $\mathrm{SDH}$, respectively, were caused by loss of cells from the substrate under submaximal denaturation conditions. Most of the protein of dentin, largely collagen, was highly insoluble under these routine methods. Also, phenol concentrations up to $0.5 \mathrm{M}$ had essentially no effect on filtration rates or upon protein patterns from powderized dentin disks on anion exchange columns. Patterns of uptake of FDA and Hoechst 33258 were also useful and complementary. The ability of cells to transport FDA was a quick method of showing viability and relative numbers of cells either on glass or dentin substrates. Hoechst 33258 was taken up by all cells on the substrate as well as those floating in the medium and gave good distinction between living and "dead" cells. The increased intensity of nuclear fluorescence in dead cells suggested that membrane transport limits the amounts of stain which can accumulate in the nuclei, and that increased membrane permeability of dead and dying cells facilitates increased diffusion of Hoechst 33258 for binding to DNA. Both fluorescent stains gave the added advantage of revealing cells on thick or opaque substrates such as dentin using epifluorescence microscopy

When various phenol concentrations in tissue culture medium were added to the reservoir on the coronal surfaces of $0.5 \mathrm{~mm}$ dentin disks in the IVPC apparatus, there was a dilution of the effects of phenol on both Balb/c 3 T3 cells and L-929 cells (Figs. 6, 7). This observation was true for Balb/c 3T3 cells both when the cells were plated directly on the pulpal surfaces of the EDTA- 


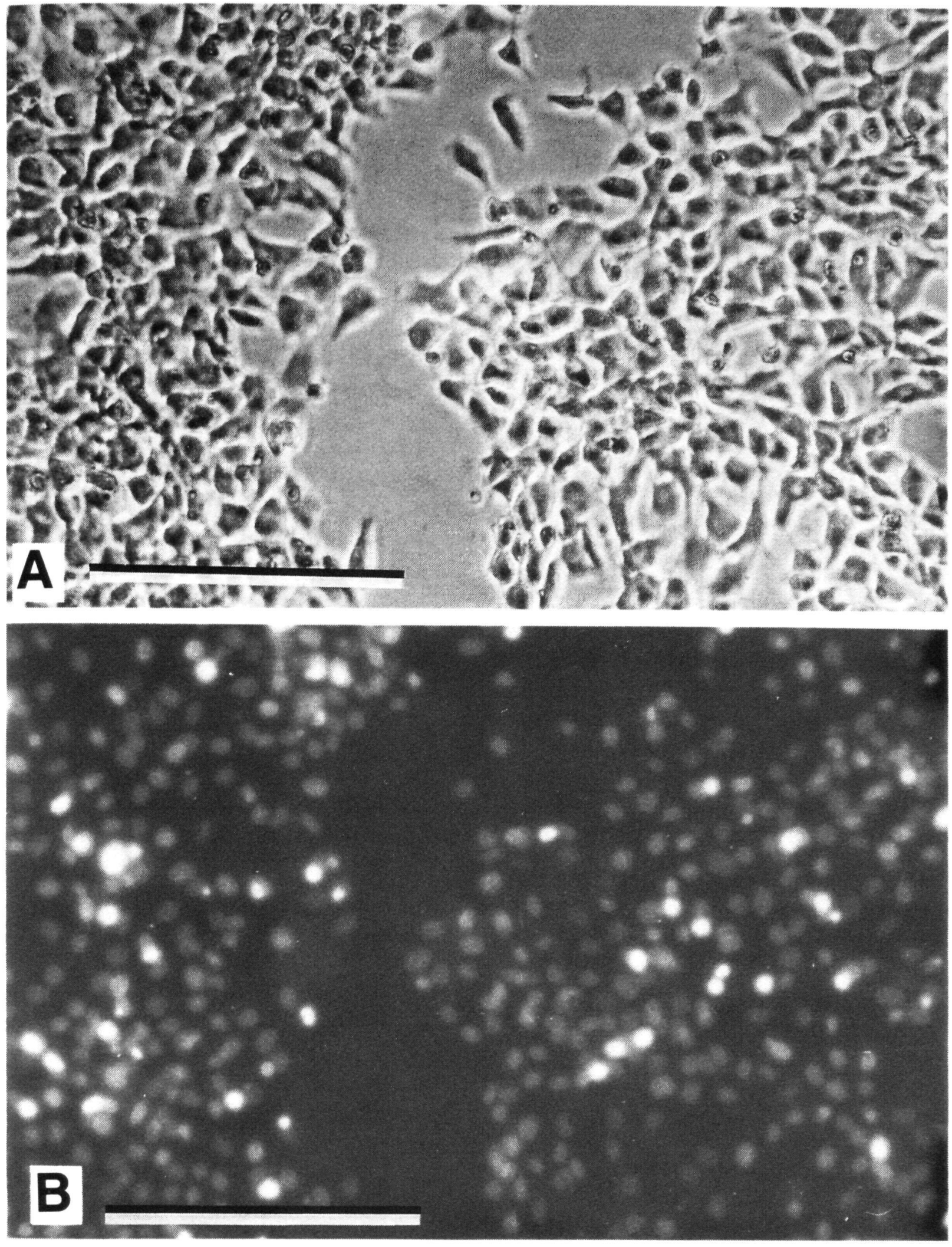

Fig. 10. Balb/c 3T3 cells directly exposed to $5 \times 10^{-3} \mathrm{M}$ phenol. Phase contrast microscopy (A) shows slight contraction of cellular processes and areas without cells where they were lost from the substrate; fluorescence microscopy (B) of same field stained with Hoechst 33258 cells again indicates that most cells are living (nuclei fluoresce faintly) with only a few dead cells (brightly fluorescing nuclei) scattered throughout the field. $(\mathrm{Mag} .=\mathrm{X} 108$; bars $=$ $250 \mathrm{um}$.

treated disks and when they were plated on glass coverslips at the bottom of each chamber. Phenol diffusion through dentin disks decreased gradually in proportion to increased dentin thickness, whether there was a smear layer present or not (Fig. 5). There was an overlapping of values, and any distinction between disks with and without smear layers would probably be removed with a larger number of samples. As the disks became thinner $(0.5$ $\mathrm{mm}$ and less), the amount of phenol diffusing the lower chamber rose more dramatically. These data are reminiscent of the theoretical graph presented previously by Pashley correlating diffusion of solute and dentin thickness (26).
In the previously reported composite study (1), thicker dentin $(1.5 \mathrm{~mm})$ protected the tests cells from diffusing substances better than thinner disks $(0.5$ $\mathrm{mm}$ ), as predicted by Pashley (25) and as shown for phenol in Fig. 5 of this paper. Thus, for purposes of in vitro or in vivo assays, the dentin thickness may be too great to allow appreciable diffusion. That is, tests with dentin over 1.0 $\mathrm{mm}$ thick would falsely suggest that the material was not toxic. Disks of about $0.5 \mathrm{~mm}$ and below begin to show sufficient diffusion to allow one to distinguish efficacious treatment of the floor of the cavity preparation for sealing the pulp from the environment. For example, if $5 \times 10^{-3} \mathrm{~m}$ phenol (which de- presses new protein synthesis with direct contact to about $50 \%$ of negative controls) were placed in the top reservoir of the $0.55 \mathrm{~mm}$ disk (which will dilute the molecule 500 times through a diffusion gradient), the resulting level of exposure to the odonotoblastic layer would be only $1 \times 10^{-5} \mathrm{~m}$ phenol, which is non-toxic, i.e. does not depress protein synthesis. Thus, when using dentin disks to restrict permeability and to more closely simulate usage studies, it is also necessary and of practical advantage to use higher concentrations of phenol or other test substances (e.g. a phenol concentration greater than $10^{-2}$ $\mathrm{M}$ ) in the coronal reservoir than would normally be placed directly in the medium in order to observe a response. Furthermore, contrary to assays for cytotoxicity in which there is direct contact between test cells and the experimental sample $(2,6,8,26-29)$, special distinction does not have to be made between liquid and solid samples when using the IVPC device (1). The IVPC device was developed to test the diffusibility of toxic substances which are eluted from materials placed against dentin. With a dentin barrier, the materials cannot have an effect on the cells system unless they are soluble to some extent in an aqueous solution and there is liquid continuity across the barrier provided by culture medium or interstistial fluid.

Fig. 6 compares new protein synthesis, in practical terms, in Balb/c 3T3 cells under the three situations being investigated. For all dentin disks, the smear layer was uniformly removed so that the disks were as permeable as possible. The data thus represent the most permeable conditions for dentin disks approximately $0.55 \mathrm{~mm}$ in thickness. The effects of phenol, at each of the various concentrations, on cells growing on the pulpal side of the dentin disks fell between effects of the same concentrations of phenol in direct contact with the cells and the effects when the cells were at the bottom of the IVPC chamber. In the latter case, phenol was further diluted by the chamber volume $(1.87 \mathrm{ml})$, as was the case in the first study with composite resins (1). Thus, in the present study $0.05 \mathrm{M}$ phenol almost completely inhibited new protein synthesis when in direct contact with the cells. However, for these 0.55 mm EDTA-treated dentin disks, the same concentration of phenol only reduced protein synthesis in cells on the underside of the disk to $60 \%$ of the 
106 Hanks et al.

Table 1. Relationship of phenol concentration and Balb/c 3T3 cell number, morphology and metabolism.

\begin{tabular}{|c|c|c|c|c|c|c|}
\hline \multirow[t]{3}{*}{ [Phenol] } & \multicolumn{2}{|c|}{ Phase contrast microscopy } & \multicolumn{3}{|c|}{ **Fluorescence microscopy } & \multirow{3}{*}{$\begin{array}{c}\text { Enzyme histochemistry } \\
\begin{array}{c}\text { Succinyl dehydrogenase } \\
\text { activity }\end{array}\end{array}$} \\
\hline & \multirow{2}{*}{$\begin{array}{l}{ }^{*} \text { No. cells } \\
\text { attached } \\
\text { to substrate }\end{array}$} & \multirow{2}{*}{$\begin{array}{c}\text { Cell } \\
\text { morphology }\end{array}$} & \multirow[t]{2}{*}{ FDA } & \multicolumn{2}{|c|}{ Hoechst 33258} & \\
\hline & & & & Faint & Bright & \\
\hline $0.0 \mathrm{M}$ & +++ & $\begin{array}{l}\text { Large "lacey" } \\
\text { cells }\end{array}$ & +++ & +++ & 0 & $\begin{array}{l}\text { Even staining through } \\
\text { cytoplasm }\end{array}$ \\
\hline $0.00005 \mathrm{M}$ & +++ & $\begin{array}{l}\text { Large "lacey" } \\
\text { cells }\end{array}$ & +++ & +++ & 0 & $\begin{array}{l}\text { Even staining through } \\
\text { cytoplasm }\end{array}$ \\
\hline $0.0005 \mathrm{M}$ & +++ & $\begin{array}{l}\text { Some contraction of } \\
\text { cell processes } \\
\text { Small gaps between } \\
\text { cells }\end{array}$ & +++ & +++ & 0 & $\begin{array}{l}\text { Even staining through } \\
\text { cytoplasm }\end{array}$ \\
\hline $0.005 \mathrm{M}$ & ++ & $\begin{array}{l}\text { Most cells contracted } \\
\text { with gaps between } \\
\text { cells. } \\
\text { Slight reduction } \\
\text { in cell number }\end{array}$ & +++ & ++ & + & $\begin{array}{l}\text { Dense staining around } \\
\text { nuclei of cells }\end{array}$ \\
\hline $0.05 \mathrm{M}$ & + & $\begin{array}{l}\text { Most cells floating, } \\
\text { contracted, individual }\end{array}$ & 0 & - & $+1-$ & No staining evident \\
\hline $0.1 \mathrm{M}$ & ++ & $\begin{array}{l}\text { Cells in sheets. } \\
\text { Some sheets floating, } \\
\text { some attached }\end{array}$ & 0 & 0 & ++ & No staining evident \\
\hline $0.5 \mathrm{M}$ & +++ & $\begin{array}{l}\text { Cells in sheets, } \\
\text { attached to substrate }\end{array}$ & 0 & 0 & +++ & No staining evident \\
\hline
\end{tabular}

\footnotetext{
* Estimation of relative number and morphology of cells on glass or plastic substrates by phase contrast microscopy.

** Fluorescein diacetate was used as a $1.5 \%$ (wt/vol) solution in $0.85 \% \mathrm{NaCl}$. It is a vital stain which accumulates in the cytoplasm of living cells. The cells stain intensely if alive or they don't if dead. The proportion of cells with fluorescence is indicated by $0-->+++$. Hoechst 33258 was used as a $30 \mu \mathrm{M}$ solution in tissue culture medium. The dye binds to DNA of living cells faintly and to DNA of dead or dying cells more brightly. The proportion of cells fluorescing is indicated by $0-->+++(+/-=$ less than $10 \%$ of negative control values).
}

negative control values. And, in cells on glass coverslips at the bottom of the IVPC chamber there was essentially no inhibition of protein synthesis. Cells in the pulp would experience dilutions of phenol intermediate between that at the pulpal surface of the dentin (odontoblasts) and that at the glass coverslip (cells deepest in the pulp) in Fig. 6, because of diffusion gradients. Also, because of the relatively low molecular weight of phenol, this would be a "worst" case. Larger molecules would diffuse more slowly (30). The effects of phenol diffusion upon cells growing on the bottom surface of the dentin would coincide more closely with the clinical response of the superficial pulp where about $0.5 \mathrm{~mm}$ dentin is left in the cavity preparation and there is no attempt at sealing or lining the cavity preparation.

For the purposes of an in vitro assay of cytotoxicity, the most useful data from this study were those of protein synthetic activity (Fig. 2). A linear relationship occurred between $5 \times 10^{-4}$ and $5 \times 10^{-2} \mathrm{M}$ phenol concentration, allowing a standardization of doses that inhibited protein synthesis between about $85 \%\left(\mathrm{ID}_{15}\right)$ of the negative control at $5 \times 10^{-4} \mathrm{M}$ phenol and about $8 \%$
$\left(\mathrm{ID}_{92}\right)$ of the negative control at $5 \times 10^{-2}$ $\mathrm{M}$ phenol. In adapting the positive control to this assay in various laboratories, the exact concentrations of phenol will vary slightly. Each time the phenol series is performed in a laboratory, these values should be "averaged in" to develop a standard curve (linear regression line) with standard deviations for the biological reaction for quality control of future tests. The phenol control (positive) should be run each time the test is run for quality control of the experimental protocol including the cells, the medium and the experimental conditions. The linearity between phenol concentrations and protein synthetic activity in Balb/c 3T3 cells exists at all times between 2 and 24 hours (unpublished data). The significance of this consistent linearity is that it allows for an assay of a shorter period of time, so that artifacts arising from long exposure to phenol (e.g. loss of cells from the substrate in presence of highly toxic substances) or strict sterility of the system may not be necessary.

The present study and cytotoxicity assay method differ from previous studies $(3,26,31)$ utilizing phenol as a positive control substance in 2 ways: the present method (a) utilizes a dentin diffusion barrier between test material and the cell system rather than direct contact, and (b) uses protein synthesis as a measure of metabolic function rather than membrane permeability. The reason for this is that toxic substances may inhibit DNA synthesis, but protein synthesis may still continue for some time. By the time cells begin to leak ${ }^{51} \mathrm{Cr}$, they are dead or dying and protein synthesis has stopped. Thus, the fraction of cells which are dead, but not the degree of sublethal injury, is measured by ${ }^{51} \mathrm{Cr}$-release. However, for cells which are terminally differentiated and are not synthesizing DNA, as apparently are primary and secondary odontoblasts which have started producing an extracellular matrix, protein synthesis would appear to be a more relevant metabolic funtion to measure than either DNA synthesis of ${ }^{51} \mathrm{Cr}$-release.

\section{Summary and conclusions}

1. Phenol was an appropriate positive control substance for this assay method because it is a small, soluble organic 
molecule, the toxic effects of which are gradual and extend linearly between $5 \times 10^{-4}$ and $5 \times 10^{-2} \mathrm{M}$, when in direct contact with the cells. This range of concentration and the effects on protein synthesis offer good reproducibility and a reference for comparing toxic effects of extracts of other dental materials. While the concentration of a toxic extract in the medium or the diffusate may not be known, it may still be referenced in terms of the same effect (e.g. $50 \%$ inhibitory dose; ID $_{50}$ ) by the positive control substance.

2. The "dentin barrier" in vitro dilutes the concentration and effects of phenol reaching the cells cultured on the "pulpal" surface of dentin in the IVPC. The degree of dilution depends mainly on the dentin thickness. It makes little difference whether a smear layer is present or not on the dentin.

3. EDTA-treated dentin disks were used in a practical experiment in the IVPC to determine the effect of position of the cell layer on new protein synthesis. Cells on the pulpal surface of dentin disks in the IVPC experienced more severe toxicity than cells on glass coverslips at the bottom of the chamber. This indicated that the medium in the chamber further diluted the phenol, and suggests that cells deep in the dental pulp are much better protected from the direct affects of toxic compounds than are odontoblasts and surrounding cells. Of course, subsequent secondary inflammatory changes may expand the zone of cell death and necrosis beyond the cells adjacent to the dentin.

Acknowledgments - This work was supported by the National Institute of Dental Research grant no. DE07987. The authors appreciate the assistance of Dr. K. K. Makinen for the FPLC experiments.

\section{References}

1. Hanks CT, Craig RG, Diehl M, et al. Cytotoxicity of dental composites and other dental materials in a new in vitro device. J Oral Pathol 1988 (in press).

2. Hanks CT, Anderson M, Craig RG. Cytotoxic effects of dental cements on two cell culture systems. J Oral Pathol 1981; 10: 101-12.
3. Spangberg L. Kinetic and quantitative evaluation of material cytotoxicity in vitro. Oral Surg 1973; 35: 389-401.

4. Sudilovsky O. A tissue culture method for toxicity testing of biomaterials. TCA Manual 1977; 3: 607-12.

5. Leininger RI, Bigg DM. Polymers. In vON ReCUM AF, ed. Handbook of biomaterials evaluation. New York: Macmillan, 1986: 24-37.

6. Hensten-Pettersen A, Helgeland K. Evaluation of biologic effects of dental materials using four different cell culture techniques. Scand J Dent Res 1977; 85: 291.

7. Meryon, SD, Riches DWH. A comparison of the in vitro cytotoxicity of four restorative materials assessed by changes in enzyme levels in two cell types. $J$ Biomed Mat Res 1982; 16: 519-28.

8. Wennberg A, Muör IA, Hensten-PetTERSEN A. Biological evaluation of dental restorative materials - comparison of different test methods. J Biomed Mat Res 1983; 17: 23-36.

9. Muör IA, Hensten-Pettersen A, SkoGEDAL O. Biologic evaluation of filling materials. A comparison of results using cell culture techniques, implantation tests and pulp tests. Int Dent J 1977; 27: 124-9.

10. Hume WR. The pharmacologic and toxicological properties of zinc oxide-eugenol. J Am Dent Assoc 1986; 113: 789-91.

11. Meyer AE. Reference materials. In: von Recum AF, ed. Handbook of biomaterials evaluation. New York: Macmillan, 1986: 131-9.

12. MERYON SD. The influence of dentine on the in vitro cytotoxicity testing of dental restorative materials. J Biomed Mat Res 1984; 18: 771-9.

13. Pearse AGE. Histochemistry: theoretical and applied. Vol. 2. Baltimore: Williams \& Wilkins, 1972: 1342.

14. Reeder OW, Walton RE, Livingston MJ, et al. Dentin permeability: determinants of hydraulic conductance. J DENT RES 1978; 57: 187-93.

15. Outhwaite WC, McKenzie DM, PashLEY DH. A versatile split-chamber device for studying dentin permeability. $J$ Dent Res 1974; 53: 1503.

16. Pashley DH, Livingston MJ, OuthWAITE WC. Rate of permeation of isotopes through human dentin, in vitro. $J$ Dent Res 1977; 56: 83-8.

17. Harvey SC. Antiseptics and disinfectants; fungicides; ectoparasiticides. In: Gilman AG, Goodman LS, Rall RW et al., eds. The pharmacological basis of therapeutics. New York: Macmillan, 1985: 959-79.

18. Ribi E, Milner KC. Bacterial antigens.
1. Disruption of bacteria and preparation of cell walls. In: Williams CA, Chase MW, eds. Methods in immunology and immunochemistry. Vol. I. New York: Academic Press, 1967: 13-28.

19. Levine L, Murakami WT. Nucleic acid analysis. 1. Methods for characterizing deoxyribonucleic acid immune systems. In: Williams CA, Chase MW, eds. Methods in immunology and immunochemistry. Vol. II. New York: Academic Press, 1967: 317-28.

20. Passi S, Picardo M, Nazzaro-Porro M. Comparative cytotoxicity of phenols in vitro. Biochem J 1987; 245: 537-42.

21. StannaRD JG. Improvements of zinc oxide-eugenol dental cement by polymerization and modification of eugenol and isoeugenol. Thesis. Ann Arbor, Michigan: The University of Michigan, 1981.

22. Wilson AD, Batchelor RF. Zinc oxide-eugenol cements: II. Study of erosion and disintegration. J Dent Res 1970; 49: 593-98.

23. Fotos PG, Woolverton CJ, van Dyke $\mathrm{K}$, Powell RL. Effects of eugenol on polymorphonuclear cell migration and chemoluminescence. J Dent Res 1987; 66: 774-7.

24. Lindquist L, Otteskog P. Eugenol: liberation from dental materials and the effect on human diploid fibroblast cells. Scand J Dent Res 1981; 89: 552-6.

25. Pashley DH, Dentin-predentin complex and its permeability: Physiologic overview. J Dent Res 1985; 64 (sp iss): 613-20.

26. Wennberg A. An in vitro method for toxicity evaluation of water soluble substances. Acta Odontol Scand 1976; 34: 33-41.

27. Hanks CT, Bergenholtz G, Kim J-S. Protein synthesis in vitro, in the presence of $\mathrm{Ca}(\mathrm{OH})_{2}$-containing pulp-capping medicaments. J Oral Path 1983; 12: 356-65.

28. Leiskar J, Helgeland K. A methodologic study of the effect of dental materials on growth and adhesion of animal cells in vitro. Scand J Dent Res $1972 ; 80$ : 120-33.

29. Kawahara H, Yamagami A, NaKamURA M. Biological testing of dental materials by measns of tissue culture. Int Dent J 1968; 18: 443-67.

30. Pashley DH, Livingston MJ. Effect of molecular size on permeability coefficients in human dentine. Arch Oral Biol 1978; 23: 391-5.

31. Spangberg L. Biologic effects of dental materials 1 . Toxicity of root canal filling materials on HeLa cells in vitro. Oral Surg 1973; 35: 402-14. 
This document is a scanned copy of a printed document. No warranty is given about the accuracy of the copy. Users should refer to the original published version of the material. 